$12-24-2018$

\title{
Investigating Diversity in Social Work Doctoral Education in the United States
}

\author{
Matthew Chin \\ Fordham University \\ Jaclynn Hawkins \\ The University Of Michigan \\ Amy Krings \\ Loyola University Chicago, akrings@luc.edu \\ Carolyn Peguero-Spencer \\ Fordham University \\ Lorraine Gutiérrez \\ Emlloetsthis of Mdiaflititipnal works at: https://ecommons.luc.edu/socialwork_facpubs \\ Part of the Social Work Commons
}

\section{Author Manuscript}

This is a pre-publication author manuscript of the final, published article.

\section{Recommended Citation}

Chin, Matthew; Hawkins, Jaclynn; Krings, Amy; Peguero-Spencer, Carolyn; and Gutiérrez, Lorraine. Investigating Diversity in Social Work Doctoral Education in the United States. Journal of Social Work Education, 54, 4: 762-775, 2018. Retrieved from Loyola eCommons, Social Work: School of Social Work Faculty Publications and Other Works, http://dx.doi.org/10.1080/10437797.2018.1503127

This Article is brought to you for free and open access by the Faculty Publications and Other Works by Department at Loyola eCommons. It has been accepted for inclusion in Social Work: School of Social Work Faculty Publications and Other Works by an authorized administrator of Loyola eCommons. For more information, please contact ecommons@luc.edu.

\section{c) (i) $\odot$}

This work is licensed under a Creative Commons Attribution-Noncommercial-No Derivative Works 3.0 License.

(c) Taylor \& Francis, 2018. 


\title{
Investigating Diversity in Social Work Doctoral Education in the United States
}

\author{
Matthew Chin, Jaclynn Hawkins, Amy Krings, Carolyn Peguero-Spencer \& Lorraine Gutiérrez
}

\section{Notes on contributors}

Matthew Chin is an Assistant Professor at Fordham University, Jaclynn Hawkins is an Assistant Professor at University of Michigan, Amy Krings is an Assistant Professor at Loyola University Chicago, Carolyn Peguero-Spencer is a doctoral student at Fordham University, and Lorraine Gutiérrez is Director, Diversity, Equity, and Inclusion Program; and Professor of Social Work, School of Social Work, Arthur F. Thurnau Professor, Professor of Psychology, College of Literature, Science, and the Arts at the University of Michigan.

\section{Corresponding Author}

Matthew Chin, mchin17@fordham.edu, Graduate School of Social Service, Fordham University, 113 W 60th Street, New York, NY 10023.

\section{Copyright Agreement}

The Version of Record of this manuscript has been published and is available in the Journal of Social Work Education, 2018, DOI: 10.1080/10437797.2018.1503127

\section{Complete Citation}

Matthew Chin, Jaclynn Hawkins, Amy Krings, Carolyn Peguero-Spencer \& Lorraine Gutiérrez (2018): Investigating Diversity in Social Work Doctoral Education in the United States, Journal of Social Work Education, DOI: 10.1080/10437797.2018.1503127

\footnotetext{
ABSTRACT

Despite its emphasis on social justice, social work in the United States has not always attended to issues of diversity in doctoral education. This article examines the state of the discipline's research on traditionally underrepresented students in U.S. doctoral social work programs. An analysis of relevant peer-reviewed articles from social work journals revealed that this research has focused on demographic trends, degree motivation, student barriers, existing supports, and career navigation. Diversity in U.S. doctoral social work education is vastly understudied with the majority of scholarship focusing on ethnoracial difference. The limitations of this study are discussed, and future research directions are proposed including the need to examine various kinds of social differences and a wider range of support initiatives.
} 


\section{Investigating Diversity in Social Work Doctoral Education in the United States}

Matthew Chin, Jaclynn Hawkins, Amy Krings, Carolyn Peguero-Spencer \& Lorraine Gutiérrez

As indicated by the Carnegie Initiative on the Doctorate, doctoral education is intended to prepare students to be stewards of their discipline (Walker, Golde, Jones, Bueschel, \& Hutchings, 2009). In the realm of social work, doctoral education is particularly important given the centrality of the profession in the historical formation and the ongoing construction of life in the United States (Haynes \& Mickelson, 2006; National Association of Social Workers [NASW], 2015; Stern \& Axinn, 2017; Trattner, 2007). With the election of Donald Trump to the office of U.S. president, social work scholars, researchers, and practitioners have insisted that more than ever the profession must continue to ensure the well-being of people in the United States (particularly its most vulnerable members) and sharpen its focus on promoting social justice (NASW, n.d.; Park, Wahab, \& Bhuyan, 2017; Reardon, 2017; Scheyett, 2017; Williams, 2017). This urgency is even more acutely felt given the present demographic profile of social work faculty in the country as many senior leaders in the field are near retirement age (Acquavita \& Tice, 2015; Anastas \& Kuerbis, 2009; Zastrow \& Bremner, 2004). It is therefore a crucial time to examine U.S. doctoral social work education as a process to prepare members of the profession for leadership.

The issue of diversity in social work doctoral education is a particularly important area of investigation. There are many ways of approaching this topic as the word diversity may refer to differences in doctoral education in terms of the extent to which curricula address questions of social difference (Hudson, Shapiro, Ebiner, Berenberg, \& Bacher, 2017), the social positioning of social work faculty (Hughes, Horner, \& Velez Ortiz, 2012), the way doctoral programs are structured (Biegel, Hokenstad, Singer, \& Guo, 2006), debates over the balance of the research, teaching and practice dimensions of doctoral training (Anastas \& Videka, 2012; Belcher, Pecukonis, \& Knight, 2011; Fong, 2014), and the emphases placed on different kinds of knowledge (Tucker, 2008), to name a few. For the purposes of this article, we are concerned with diversity in terms of the differences among students in social work doctoral programs. We are interested in diversity not just as benign difference but the way that differences among doctoral students are closely tied to questions of power, hierarchy, and inequality. This focus on student diversity moves away from an essentializing and superficial analysis of identity politics and instead attends to how doctoral students are faced with different sociocultural, economic, and political realities that fundamentally ground the nature of their experiences in social work education. We are particularly interested in understanding the ways in which dynamics of gender, sex, ethnoracial difference, able-bodiedness, class, religion, citizenship, and generational access to education come to bear on the lives of existing (and potential) social work doctoral students. 
Although educational scholars have insisted on the importance of attending to difference among doctoral students as a means of ensuring the democratization of the production of scientific knowledge (Bancroft, 2013; Holley \& Joseph, 2013; Squire, 2015), these questions take on added significance in the field of social work not only because of its emphasis on fostering social justice in the profession's educational institutions (Council on Social Work Education [CSWE], 2017a) but also because of its commitment to improving the well-being of society more generally, particularly its more vulnerable members (NASW, 2017). Although researchers have investigated how the social positioning of social work practitioners is consequential for outcomes such as individual client wellbeing and organizational success (Acquavita, Pittman, Gibbons, \& Castellanos-Brown, 2009; Ely, Padavic, \& Thomas, 2012; McBeath, Chuang, Bunger, \& Blakeslee, 2014; Perry \& Limb, 2004), fewer studies have extended this research to consider similar questions of diversity at the doctoral level. Having a clearer picture of who social work doctoral students are (and who they are not), how they are doing in their programs, and how these trends play into existing social hierarchies are important areas of social work scholarship. The CSWE annual survey of social work programs in the United States is an important first step in this regard. According to the 2016 report, of the 611 students enrolled in practice doctorates and the 2,325 students enrolled in research doctorates, more than $70 \%$ are female and more than $40 \%$ are from historically underrepresented (ethnoracial) groups (CSWE, 2017b). Yet a more nuanced approach to the study of difference and power is necessary as the survey does not address other crucially important dimensions of diversity such as class, sexual orientation, religion, and disability status, to name a few. Examining how schools of social work attend to the range of differences among their existing (and potential) doctoral students is important because it serves as a means to examine how dynamics of power influence training the next generation of social work leaders.

This topic has not been adequately addressed in the literature on social work doctoral education in the United States. There has been little attention to the factors, institutional practices, and broader conditions that affect social differences among students in social work doctoral programs, including recruitment considerations, the nature of these differences, and the consequences of these differences in terms of student treatment in doctoral programs and measures of student success. Given the paucity of empirical data on this topic, in this article we offer a literature review on diversity and social work doctoral education to understand the current state of knowledge in the field.

Diversity scholars like Ahmed $(2012,2017)$ have cautioned us on how the language of diversity can be used to reproduce problematic institutional dynamics. Ahmed illustrates how commitments to diversity in academia operate as "non-performatives" $(2012$, p. 117) by simultaneously obscuring the work of racism even as they uphold institutional whiteness. Ahmed's work compels us to consider not only diversity in and of itself but how difference is mobilized in relation to the workings of power, oppression, and inequality. Her insights on the difference between "diversity work" (2012, p. 30) (efforts to transform institutions) and "the 
work of diversity" (2012, p. 135) (the consequences of institutional change efforts) have informed the way we have approached this literature review (Ahmed, 2017). We thus recognize that even as we emphasize the need to attend to underrepresented students in U.S. doctoral social work programs, these efforts may be taken up by academic institutions in unforeseen and potentially problematic ways. Our methods and analysis are thus informed by a strategic attention to how issues of diversity and difference are framed in existing scholarship on social work doctoral education and how the results of this review might subsequently be mobilized.

\section{Methods}

We performed a search to retrieve and analyze peer-reviewed articles addressing issues of diversity among social work doctoral programs using a four-tiered matrix method (Garrard, 2011). We chose this method because it has been widely used in a number of peer-reviewed articles across various disciplines to produce quality literature reviews (Goldman \& Schmallz, 2004; Klopper, Lubbe, \& Rugbeer, 2007). The method is divided into four sections: paper trail (literature search), documents (organizing documents for the review), review matrix (abstracting each document), and synthesis (writing the review of the literature). For this review, a paper trail was first set up by compiling a list of databases and identifying which search terms would be used. We searched major literature databases (Ebscohost, ProQuest, and PubMed,) to identify potentially eligible studies related to our research topic. A combination or variation of the following search terms were used to define diversity: race, ethnicity, diversity, underrepresented, minority, gender, sexual orientation, socioeconomic status, first generation, citizenship status, immigrant, LGBT, class, disability, religion, and international. Peer-reviewed articles were included; technical reports, dissertations, books, editorials, and book reviews were excluded.

Our search resulted in many studies that did not fit our selection criteria and were not published in social work journals. As a result, we conducted a second search, using the same terms to capture our definition of diversity while adding the term doctoral to further narrow the search. This resulted in 374 articles. From these results, we excluded duplicates and articles published in non-social-work journals and articles that were based on research conducted outside of the United States. Two research investigators then reviewed the titles and abstracts of the remaining articles to determine eligibility for inclusion in the literature review based on their relevance to diversity in social work doctoral education. If disagreement arose regarding eligibility for inclusion, an additional investigator was asked to evaluate the article, and resolutions were reached through discussion. Ultimately, our search resulted in 11 articles. Because our search resulted in so few articles, we did not place a time limit on the studies included in our review. The date of the last search was August 2017. For Step 2 (documents section) and Step 3 (review matrix), we organized the 11 papers chronologically, created a review matrix, and read through each article. The review matrix included the following categories: author or authors, title, of journal, year published, purpose, study design, sample size, and main findings. 
Once identified, articles were analyzed based on our professional experience as researchers and practitioners working with underrepresented doctoral students in social work with an eye toward barriers and supports. The full journal articles were read and reviewed by two research investigators (Chin and Hawkins) to identify key themes, and a synthesis was written based on the review matrix. Both research investigators reviewed and analyzed each of the articles and consulted with the third investigator (Krings) in cases where disagreement arose based on categorization of themes.

\section{Results}

The 11 peer-reviewed articles resulting from our search were published between 1979 and 2017. Although these 11 studies used various methodologies, the majority employed qualitative (focus groups, autoethnography, interviews, case studies) as opposed to quantitative (survey) approaches. The number of studies on this subject appears to have grown over almost 4 decades as four of the studies were published between 1979 and 2006, and the remaining seven studies were published between 2007 and 2017. For more details about these studies, see Table1.

Our analysis of the literature revealed five topical areas that characterize social work scholarship on issues of diversity among students enrolled in social doctoral programs in the United States: demographic shifts in social work education, factors motivating the decision to pursue a $\mathrm{PhD}$, barriers to accessing or completing doctoral programs, support structures and recommendations, and career navigation. Next we discuss these themes in the contexts of the articles we reviewed.

Table 1. Literature reviewed on issues of diversity in U.S. social work doctoral programs.

\begin{tabular}{|c|c|c|c|}
\hline Author, Authors & Purpose or Study Design & Method Characteristics & Findings \\
\hline $\begin{array}{c}\text { Creecy et al. } \\
\text { (1979) }\end{array}$ & $\begin{array}{l}\text { To understand the decision making } \\
\text { of ethnoracial minorities to pursue } \\
\text { social work doctoral education and } \\
\text { the problems they face in social } \\
\text { work doctoral programs }\end{array}$ & $\begin{array}{l}\text { Nationwide survey of } 144 \\
\text { ethnoracial students enrolled in } \\
\text { social work doctoral programs }\end{array}$ & $\begin{array}{l}\text { Participants decided to pursue } \\
\text { doctoral studies after completing } \\
\text { their MSW, were influenced by a } \\
\text { teacher or employer, and sought } \\
\text { to obtain a PhD to expand their } \\
\text { knowledge or contribute to the } \\
\text { field. The barriers they faced in } \\
\text { social work doctoral programs } \\
\text { included problems adjusting to } \\
\text { the academic and social } \\
\text { environment, family and personal } \\
\text { problems, and problems with } \\
\text { racism. }\end{array}$ \\
\hline Davis (2016) & $\begin{array}{l}\text { To understand the use of reflexive } \\
\text { practices, such as keeping journals, } \\
\text { to foster antiracist practice }\end{array}$ & $\begin{array}{l}\text { Analysis of journal entries from six } \\
\text { social work doctoral students in a } \\
\text { six-session antiracism project using } \\
\text { narrative inquiry }\end{array}$ & $\begin{array}{l}\text { The themes of authenticity, } \\
\text { empathy, and mutuality emerged } \\
\text { as individuals engaged in the } \\
\text { process of keeping journals } \\
\text { together. The practice of } \\
\text { cultivating authenticity, empathy, } \\
\text { and mutuality can be constructive } \\
\text { in challenging racism and } \\
\text { advancing racial justice. }\end{array}$ \\
\hline
\end{tabular}


Davis and

Livingstone

(2016)

Ghose et al.

(2017) effects of racism in doctoral education

To describe hurdles students of color face in admission and retention in social work doctoral programs and to propose approaches to circumvent them
To understand the presence and
Analysis of journal entries and audio transcription of conversations among six social session antiracist project using inductive coding

Conceptual article work doctoral students in a six-

This study illustrated several themes: experiences of racism as a doctoral student, noticing White privilege in social work education, learning to teach as an antiracist educator, and anticipating racism in the job market.

Retention challenges include lack of mentorship and academic support, financial hardship, and discrimination. Suggestions include recruitment from diverse communities, de-emphasis on standardized scores and blind admission reviews, increase in faculty of color numbers, expansion of academic and financial support, and establishment of mentorship networks. At the structural level, the value accorded to different kinds of teaching, research and publication, and community engagement should be reconsidered. Finally, replacement of tenured faculty with adjuncts and the initiation of the doctorate in social work programs should be examined.

As potential diversity hires, doctoral students may navigate issues around identity negotiation, identity in conflict, and tokenism. They may also face structural or institutional forces over issues of mentoring. disciplinary concerns, and gender in hiring.

The authors suggest that this program cultivates networks of mutual help (social capital) among program participants in ways that facilitate the advancement of underrepresented ethnic social work scholars.

Howard University mentorship With a philosophical emphasis on

Ross-Sheriff, Berry To explore the mentoring program examined as a case study Edwards, and experiences of social work doctora students at historically Black colleges and universities social justice, self-determination, racial identity and pride, and social integration, social work faculty at HBCUs mentor African American and other students in $\mathrm{PhD}$ programs for academic achievement and successful leadership in the professoriate. The mentoring experiences at HBCUs are underpinned by tenets from relational and cultural theory and the Black feminist theory of other mothering. 
Schiele and Francis (1996)
To examine the academic status of former Council on Social Work Education Ethnic Minority Doctoral Fellows
Schilling et al. To illustrate the changing (2008) demographic portrait of social work education in the United States
Survey data collected from a national sample of 90 former fellows
Analysis of demographic data collected through surveys administered by the Council on Social Work Education between 1974 and 2000

Simon et al. (2004)

Tijerina and To identify factors influencing

To explore the role of mentoring the careers of African American women in the administration of social work education

in Survey data collected from 32 African American female administrators in social work education

Five focus groups conducted with 21 people who self-identify as perceptions of social work doctoral education and academia

Latino with an MSW degree and a minimum of 2 years post-MSW experience
A greater percentage of Hispanic Americans, compared to other underrepresented respondents, were full and tenured professors; a greater percentage of male than female respondents were tenured; a vast majority of the respondents who applied were awarded promotion and tenure; most of the scholarly productivity was attributed to a minority of the respondents; and respondents' publication productivity was significantly related to gender and their age when they received the doctorate.

The authors examined demographic trends across all levels of social work education. At the doctoral level, the gender makeup of social work graduates has changed significantly in the United States. Between 1974 and 2000 , the percentage of women graduates shifted from $35 \%$ to 73\%; in the same period, the gains made by people of color were less striking (from 16\% to 19\%).

Although the participants were successful in their careers, mentoring opportunities were not a part of their early career experiences. Race and gender play important roles in the type of mentoring experienced by African American women in social work academia.

Results suggest a deep commitment to making a contribution to the social work profession and Latino communities through direct practice, teaching, and field instruction. In addition to structural barriers to pursuing doctoral education, there was skepticism on the relevance of a $\mathrm{PhD}$ in serving the profession or Latino communities.

lote. $\mathrm{HBCU}=$ historically Black colleges and universities. 


\section{Demographic shifts in social work education}

One study in our search (Schilling, Morrish, \& Liu, 2008) addressed demographic trends in social work education from data collected by CSWE annual reports between 1974 and 2000 for all levels of social work education in the United States (BSW, MSW, and PhD). The article was written in an effort to describe the growth of social work education, including faculty demographics and the characteristics of social workers enrolled in and graduated from social work programs. The results indicate that the gender makeup of doctoral social work graduates has increased from 35\% women in 1974 to $73 \%$ in 2000 . The gains made by ethnoracial groups, however, are more modest, changing from $16 \%$ to $19 \%$ in this 26 -year period. The article also included data on the increase of social work bachelor's, master's, and doctoral programs from 1974 to 2000 . Schilling et al. (2008) conclude with a call for the profession to examine issues of racial, ethnic, and gender representation, given that trends indicate a significant increase in women and underrepresented racial and ethnic groups during the time period of the study.

\section{Motivation to pursue doctoral studies}

Two of the studies reviewed focused on the factors that motivated members of underrepresented ethnoracial groups to pursue social work doctorate education. Creecy, Wright, and Berg (1979) conducted a nationwide survey among 144 underrepresented ethnoracial students enrolled in doctoral social work programs in 1976. The results indicated that the decision to obtain a social work doctorate was influenced by supportive teachers or employers or was made after the student had received a master's degree and was largely motivated by a desire to increase his or her knowledge base and contribute to the field. Tijerina and Deepak (2014) conducted five focus groups with 21 Mexican American social workers to understand their perceptions of social work doctoral education. All respondents expressed a deep commitment to the field of social work and to improving the wellbeing of their communities. Some participants in the study indicated that pursuing a doctorate in social work could be useful in deepening this commitment to contributing to the field and their communities through teaching social workers how to work more effectively with Latino populations, mentoring Latino students, and engaging in research that usefully informs policy and program development.

\section{Barriers to accessing or completing doctoral studies}

Four of the studies included in our review focused on identifying barriers that individuals from different ethnoracial backgrounds face in the context of U.S. social work doctoral education (Creecy et al., 1979; Davis \& Livingston, 2016; Ghose, Ali, \& Keo-Meier, 2017; Tijerina \& Deepak, 2014). In their survey described in the preceding section, Creecy et al. (1979) indicated that students from underrepresented ethnoracial groups described three kinds of challenges to pursing their doctorate in social work: problems adjusting to the academic and social environment of the university, problems in their personal or family life, and problems associated with racial discrimination. In their study with Mexican American social workers, Tijerina and 
Deepak (2014) named several perceived barriers that study participants mentioned in obtaining a social work doctorate. Although some students viewed pursuing a $\mathrm{PhD}$ in a positive light, other participants doubted whether pursuing a $\mathrm{PhD}$ would allow them to be able to realize their goal of contributing to social work practice in Latino communities. Participants also felt that if they were to pursue doctoral studies, they would encounter similar difficulties they had faced in completing their MSW, such as having to manage family responsibilities and work while pursuing their education. These barriers would be intensified by the need to relocate to continue in their studies and by the subsequent stress of family relocation.

Davis and Livingston (2016) participated in and analyzed conversations and journal entries that emerged from an antiracist project with four other social work doctoral students. Specifically, they examined content regarding the presence and effect of racism in doctoral social work education. The project included six 90-minute discussion sessions involving all six doctoral students. Davis and Livingston analyzed the journal entries and transcripts from the audio recordings of the sessions using an inductive coding process to reveal aspects of racism that were salient to student experiences. They arrived at the following four themes: the ways doctoral students experience racism in their social work programs, how they become aware of White privilege, the ways students learned to become antiracist educators, and how attention to racism came to be part of the process of preparing doctoral students for the job market.

Although Ghose et al. (2017) did not collect data directly from students, they present a thought piece that outlines barriers students of color experience when pursuing a $\mathrm{PhD}$ in social work. They categorized barriers as structural and institutional, including a high reliance on Graduate Record Examination scores, and a lack of funding in $\mathrm{PhD}$ programs that discourage already socioeconomically disadvantaged candidates. In addition, they stated that limited mentorship for $\mathrm{PhD}$ candidates and lack of diversity among faculty diminishes the student-of-color pipeline to doctoral education. They also argue that students of color are encouraged to pursue DSW degrees, which are often considered to be lower in status and less research focused than $\mathrm{PhD}$ degrees. They further maintain that students of color who are DSW graduates often lose out on the job market for tenure-track faculty positions to $\mathrm{PhD}$ program graduates and instead find themselves in faculty positions without the benefit of tenure or permanent placement.

\section{Support structures and recommendations}

Studies included in our review also captured efforts that programs have made to support underrepresented ethnoracial doctoral students (Davis, 2016; Ghose, Ali, \& Keo-Keier, 2107; Pinto \& Francis, 2005; Ross-Sheriff, Berry Edwards, \& Orme, 2017; Schiele \& Francis, 1996; Simon, Bowles, King, \& Roff, 2004). These studies identified a range of sources that support U.S. social work doctoral students from underrepresented backgrounds, including other students, faculty, and educational institutions. 
In providing further details of the antiracist project described in the previous section, Davis (2016) suggests that the use of critical reflexivity through activities like journal keeping is a method that social work doctoral students can use to support each other in the development of antiracist practice. Davis described how the process of students pairing up to keep a journal together may bring about greater self-consciousness and mutually supported learning. She identifies three specific themes that arise from her narrative analysis of three journals produced from the project: authenticity, empathy, and mutuality. Davis maintains that cultivating authenticity, empathy, and mutuality in a reflexive and relational manner may be constructive in challenging racism and White privilege while also advancing racial justice.

Although Davis identified a specific initiative doctoral students can use to support each other, Ross-Sherriff, Berry Edwards, and Orme (2017) and Simon et al. (2004) discuss the importance of mentoring in the lives of Black and African American doctoral students. Using the Howard University School of Social Work as a case study, Ross-Sheriff et al. (2017) describe the mentoring experiences of social work doctoral students at historically Black colleges and universities (HBCUs). They describe how faculty approached students within a framework that emphasizes social justice, self-determination, racial identity and pride, and social integration. They also report that faculty focused on mentorship with specific outcomes that included academic achievement and becoming effective leaders in academia in the field of social work. Although these approaches to mentoring can be mobilized in any doctoral program, the Ross-Sheriff et al. also report on the significance of mentoring at HBCUs in particular and discuss the importance of attending to specific institutional contexts with regard to gender, race, and ethnicity in how they interact and support underrepresented students.

Simon et al. (2004) also point out the importance of mentorship in social work for underrepresented ethnoracial groups in the professoriate. They conducted a study that examined the role of mentoring in the careers of African American women in the administration of social work education through a phone survey with 14 Black women. One relevant finding was that women in the sample stated that their mentors during their doctoral program played a critical role in their successful attainment of administrative positions in schools of social work. Although the study this article is based on did not collect data from doctoral students, we decided to include this article in the literature review because much of the study addressed the experiences of interviewees while they were doctoral students.

In addition to examining how interpersonal practices (e.g., shared journals or mentoring) can support doctoral students from underrepresented ethnoracial groups, social work scholars have also explored programmatic sources of support. Pinto and Francis (2005) and Schiele and Francis (1996) analyzed the CSWE's Minority Fellowship Program (MFP), an initiative of the Center for Minority Group Mental Health at the National Institute of Mental Health, which was formed to increase research on the mental health needs of communities of color. The goals of the MFP are to increase the number of social work doctoral students of color concentrating in research, enhance the number of people of color in social work programs, and contribute to "the 
systematic development of knowledge regarding ethnic minority individuals and communities" (Styles O'Neal \& Scott, 1981, p. 2). In their conceptual article of the program, Pinto and Francis (2005) show how support from the MFP enhances the capacity of ethnoracial-group scholars to develop social networks and social capital, which in turn may facilitate enhanced research and scholarship outcomes.

Yet even as the MFP may support the success of ethnoracial doctoral social work students, survey data collected from students who took part in the program suggests that those who participate in the MFP do not necessarily have the same levels of success. Schiele and Francis (1996) analyzed data collected from a national sample of 90 former MFP participants and found that (a) a greater percentage of Hispanic-American respondents, compared to African American, Asian American, and Native American respondents, were full and tenured professors; (b) a greater percentage of male than female respondents were tenured; (c) a vast majority of the respondents who applied were awarded promotion and tenure; (d) most of the scholarly productivity was attributed to a minority of the respondents; and (e) respondents' publication productivity was significantly related to gender and their age when they received their doctorate such that women who were older when they received their doctorate published less often than their counterparts. Respondents highlighted the important role the program played in providing access to mentors who were also faculty of color to help guide them through doctoral programs and suggested that the mentoring process should be more formalized in social work $\mathrm{PhD}$ programs, particularly for students of color.

Finally, Ghose et al. (2017) focus on institutional initiatives that support ethno-racial minority doctoral students in U.S. social work programs. After identifying the challenges students of color face while in these programs, they discussed a range of practices that schools of social work should adopt to recruit, retain, and ensure the success of these students. Some of these practices include recruiting in areas that are characterized by high concentrations of members of ethnoracial groups, de-emphasizing the importance of standardized test scores in admissions decisions, increasing levels of faculty of color, fostering the development of cross-cutting mentorship networks, and expanding academic and financial support. In addition, they called for social work educators to transform relationships between universities and communities and to alter the ways research and publication are valued.

\section{Career navigation}

The final theme that emerged from our literature review was the unique challenges that underrepresented doctoral students face as they leave social work doctoral programs and attempt to forge careers for themselves. As mentioned earlier, Davis and Livingston (2016) indicate that social work doctoral students not only experience racism in their programs but they also expect racism to structure the process of securing employment after they complete their education. In their autoethnographic reflection, Hughes et al. (2012) describe the challenges associated with being a diversity hire on the academic job market including negotiating one's identity, managing 
identity conflict, and potentially addressing tokenism once hired. They point out how structural and cultural aspects of specific institutions influence the ways underrepresented candidates engage with the job market, pointing specifically to mentorship (or lack thereof), disciplinary politics, and concerns about gender. Like many studies in this review, Hughes, Horner \& Velez (2012) consider issues of ethnoracial difference and also address how issues of sexuality and family life influence the ways underrepresented doctoral students attempt to secure academic positions in social work.

\section{Discussion}

More than ever the issue of diversity in higher education in the United States has become a topic of national debate as the Trump administration has directed the Department of Justice to investigate and sue universities over affirmative action admissions policies (Savage, 2017). As a profession whose mission is to attend to the well-being of U.S. society, the field of social work experiences a unique set of challenges with this federal directive. With its commitment to social justice and supporting the well-being of vulnerable communities, social work typically opposes this kind of regressive approach to the politics of difference. This can be seen in the field of doctoral education in which schools of social work have a higher percentage of female doctoral students and doctoral students of color than other professional schools (Anastas \& Kuerbis, 2009). Because those with doctorates are trained to be stewards of their fields, it is always important to subject this training process to critical scrutiny. However, given the tense political environment in the United States over diversity and education, it is an especially pressing moment to analyze how dynamics of power, privilege, and oppression are involved in doctoral social work education.

This literature review has shown that woefully few studies examine this topic from the vantage point of diversity among social work doctoral students. Although we have the experience of being social work doctoral students and most of us are currently faculty in schools of social work, we were surprised to find how few peer-reviewed studies published in social work journals address diversity. Although few in number, these studies are significant in that they represent the current state of knowledge on diversity in doctoral social work education. The benefits of doing a literature review at such an emergent phase of this topic lie not only in clearly delineating current research approaches and findings but also in providing space to discuss the significance of the relative absence of scholarship in this area.

The scholarship covered in this review has shown that differences among U.S. social work doctoral students in terms of power, oppression, and inequality are relevant to social work doctoral education at various stages, namely, before individuals become doctoral students, while they are doctoral students, and as they make the transition out of doctoral programs. Even though they were conducted several decades apart using different methodologies, Creecy et al.'s (1979) and Tijerina \& Deepak's (2014) studies show some level of continuity as both point out that members of underrepresented ethnoracial groups are very much interested in pursuing doctorates 
in social work but that the conditions of their lives serve as barriers to accessing and completing this higher level of education. These articles raise questions about the extent to which social work doctoral programs can work not only to provide students of color with quality educational experiences but also address the conditions that serve as barriers to their entry and retention in these programs. Ghose, Ali, and Meier (2017) illustrate that these barriers exist not only in the lives of (potential) students of color but also in social work doctoral programs through gatekeeping mechanisms like high reliance on Graduate Record Examination scores.

Concerns about race follow students of color as they gain entry and make their way through social work doctoral programs in the United States. Creecy et al. (1979) and Davis and Livingstone (2016) indicate that racism is a major concern for ethnoracial-group students as they pursue their doctorates, and that it negatively affects their educational experiences. Yet Davis and Livingstone also indicate that these experiences allow these students to develop skills in areas such as antiracist pedagogy. Ghose et al. (2017) suggest that the lack of funding and faculty of color in schools of social work have a particularly detrimental effect on the success of ethno-racial minority students as both elements serve as important resources that contribute to degree completion.

Finally, as illustrated by Hughes et al. (2012), underrepresented students are often compelled to negotiate issues around diversity as they attempt to secure careers after leaving their doctoral programs (in this case Hughes et al. specifically address concerns on race, gender, sexuality, and family). These findings confirm the fears that students in Davis and Livingston's study (2016) express in terms of being worried about having to address racism on the job market. They also suggest that even though schools of social work consider "filling a diversity need" to be one of the major considerations in hiring faculty (Barsky, Green, \& Ayayo, 2014, p. 73), the process of securing faculty positions as underrepresented students leave doctoral programs is a challenging one. Yet it is important to recognize that not all doctoral students complete their degree requirements, nor do they necessarily seek academic positions after graduation. An important future area of inquiry is to examine patterns in the kinds of careers that differently positioned students obtain (or wish to obtain) after leaving their doctoral programs (whether they complete these programs or not), the experiences they face in securing these careers, and possible support mechanisms for these various professional trajectories.

The studies in this review highlight a number of different existing and proposed initiatives to support the success of underrepresented ethnoracial doctoral students at the interpersonal, programmatic, and institutional levels. Davis (2016) discusses the utility of critical reflexive journal keeping among students as a way of raising consciousness and addressing racism; Ross-Sherriff, Berry Edwards, and Orme (2017) and Simon et al. (2004) emphasize the importance of mentoring for students of color; and Pinto and Francis (2005) and Schiele and Francis (1996) highlight the effectiveness of the CSWE's MFP in supporting the success of ethnoracial-group scholars. Finally, Ghose et al. (2017) propose a wide range of institutional 
measures that schools of social work can undertake to increase the recruitment, retention and overall success of students of color.

The social work literature on the experiences of social work doctoral students from traditionally underrepresented backgrounds covered in this review has tended to focus primarily on issues of race and ethnicity. Recognizing the importance of attending to the multidimensional nature of how different mechanisms of inequality function, it is crucial for those in the profession to examine the relationship between doctoral social work education and other (intersecting) vectors of subordination such as socioeconomic status (class), disability, religion, sexuality, gender, generational access to education, and citizenship, to name a few. The studies covered in this article have also tended to approach support for traditionally underrepresented students (primarily ethnoracial) at the interpersonal and programmatic level. Although these initiatives have been shown to produce positive outcomes, we stress the significance of structural transformation such as recommended by Ghose et al. (2017) while also augmenting the efforts that traditionally underrepresented students are already engaging in to support each other such as those described by Davis (2016).

\section{Limitations and future research}

Our review of the literature illustrates the state of research relating to diversity in social work doctoral programs. However, given the limited sample of relevant peer reviewed articles $(\mathrm{N}=11)$, our interpretations are necessarily cautious and tentative. The terms used in our search, although certainly extensive, may not have fully captured the different permutations of the relationship between diversity and doctoral social work education in the United States. There may also be cases in which the title and abstract of the article do not indicate that it substantively addresses our topic of interest. Finally, articles relevant to the concerns of our research question may be published in non-social-work journals. This decentralization of the scholarship on the topic of diversity and doctoral social work education (in terms of how the literature describes itself and where it is published) is perhaps an indication of the emerging nature of this field of study. Future research might expand on scholarship on doctoral education in social work, which is not specific to questions of diversity, or scholarship on diversity in higher education, which is not specific to social work. Alternatively, it may be fruitful to consider scholarship about diversity and social work doctoral education that is not contained in peer-reviewed articles, such as books and dissertations. Finally, there is a need to collect new data as well as data that include the voices and experiences of underrepresented students in social work doctoral programs to understand their experiences, needs, and sources of support.

To begin to address these gaps in the literature, we propose the following multistage research agenda, which we believe may address these issues. The first stage involves an extension of the CSWE national survey about diversity in doctoral-level social work education. How many and what type of traditionally underrepresented students are currently enrolled in what kinds of social work doctoral programs? What are the rates of success of these students 
(e.g., graduation on time)? What point(s) in their programs do doctoral students find the most challenging? What sources of support do doctoral students consider to be most helpful? Finally, how do these patterns vary by geography and type of program ( $\mathrm{PhD}$ vs. DSW, Research 1 vs. Research 2 or Research 3, etc.)? Engaging in this kind of research endeavor will establish a comprehensive view of who is currently enrolled in doctoral social work programs, rates of success, and how these rates of success are patterned. As the United States is currently grappling with the politics of difference in higher education, it is crucial for the field of social work to generate this information as a first step to determining the kind of stewardship the profession is to produce.

The quantitative inquiry proposed could be used to construct a comprehensive nationwide sketch on the state of diversity among doctoral students in schools of social work and the extent to which traditionally underrepresented students are successful in doctoral social work programs. At the same time, qualitative approaches are better suited to investigate a deeper and more nuanced set of questions on the workings of power and inequality in how these programs function. Although quantitative approaches can be used to determine the state of the field, qualitative approaches can be used to determine the processes that produced this state of the field. The aforementioned quantitative project can be used to identify doctoral social work programs for qualitative case studies (the second stage of the research initiative). Through interviews and focus groups with faculty, administrators, and traditionally underrepresented students as well as an analysis of existing school policies on issues such as student recruitment and retention, case studies can aid in the identification of specific institutional mechanisms that either support or thwart the recruitment, retention, and success of traditionally underrepresented doctoral social work students.

Although researchers have already used case studies to examine questions of diversity in social work doctoral education, these projects have tended to focus on singular dimensions of social difference (such as race) as opposed to the way doctoral programs engage with multiple dimensions of difference. Conducting case studies that attend to how power operates, as opposed to examining the experiences of a singular underrepresented group, provides a more holistic approach to the ways inequality is produced through educational institutions. The information generated from these case studies can assist in the formulation of novel approaches, policies, and programs that can help to ensure that the way doctoral social work education is delivered is in alignment with social work values of social justice.

\section{Conclusion}

Although this article is useful in describing the nature of existing social work research on diversity among students in social work doctoral programs, it also shows that this topic is critically understudied. At this time in U.S. history, those of us in the field of social work cannot afford to continue to ignore how processes of power, oppression, and inequality operate in training the future stewards of the profession. The quantitative and qualitative research initiatives 
offered earlier can be used to develop a common set of institutional guidelines and measures to support the recruitment and success of underrepresented social work doctoral students. It is imperative to point out, however, that although it is important to attend to a politics of diversity and inclusion, it is also just as important to consider who is being included in what. As discussed earlier, diversity scholars like Ahmed (2012, 2017) have cautioned us against a depoliticizing approach to diversity in higher education that enables the perpetuation of mechanisms of inequality while superficially attending to a politics of difference. Administrators of schools of social work and social work faculty must therefore consider not only the inclusion and retention of underrepresented students but also the kinds of institutional arrangements these students are encouraged to enter and the kinds of success they are institutionally rewarded to strive toward. Researchers have already cautioned us against the way current political economic conditions, particularly the deeper retrenchment of neoliberalism, have negatively affected the provision of social work doctoral education in the United States (Hanesworth, 2017; Macías, 2015; Reisch, 2013). Thus, as we advocate for greater attention to diversity and to the status of underrepresented students in social work doctoral education, we also insist on attending to how the dynamics of power oppression and inequality shape the field of doctoral education itself. We hope this article has contributed a step in this direction.

\section{References}

Acquavita, S. P., Pittman, J., Gibbons, M., \& Castellanos-Brown, K. (2009). Personal and organizational diversity factors' impact on social workers' job satisfaction: Results from a national internet-based survey. Administration in Social Work, 33, 151-166. doi:10.1080/03643100902768824

Acquavita, S. P., \& Tice, C. J. (2015). Social work doctoral education in the United States: Examining the past, preparing for the future. Social Work Education, 34, 846-860. doi:10.1080/02615479.2015.1053448

Ahmed, S. (2012). On being included: Racism and diversity in institutional life. Durham, NC: Duke University Press.

Ahmed, S. (2017). Living a feminist life. Durham, NC: Duke University Press.

Anastas, J., \& Videka, L. (2012). Does social work need a "practice doctorate"? Clinical Social Work Journal, 40, 268- 276. doi:10.1007/s10615-012-0392-3

Anastas, J. W., \& Kuerbis, A. N. (2009). Doctoral education in social work: What we know and what we need to know. Social Work, 54, 71-81. doi:10.1093/sw/54.1.71

Bancroft, S. (2013). Capital, kinship, \& white privilege: Social \& cultural influences upon the minority doctoral experience in the sciences. Multicultural Education, 20(2), 10-16.

Barsky, A., Green, D., \& Ayayo, M. (2014). Hiring priorities for BSW/MSW programs in the United States: Informing doctoral programs about current needs. Journal of Social Work, 14, 62-82. doi:10.1177/1468017313476772 
Belcher, J., Pecukonis, E., \& Knight, C. (2011). Where have all the teachers gone? The selling out of social work education. Journal of Teaching in Social Work, 31, 195-209. doi:10.1080/08841233.2011.562103

Biegel, D. E., Terry Hokenstad, M. C., Singer, M. I., \& Guo, S. (2006). One school's experience in reconceptualizing part-time doctoral education in social work. Journal of Social Work Education, 42, 231-247. doi:10.5175/ JSWE.2006.200400454

Council on Social Work Education. (2017a). Center for Diversity and Socio-economic Justice. Alexandria, VA: Author. Retrieved from. https://www.cswe.org/Centers-Initiatives/Centers/Center-for-Diversity.aspx

Council on Social Work Education. (2017b). Statistics on social work education in the United States. Retrieved from http://www.cswe.org/CMSPages/GetFile.aspx?guid=6e8bc9e7-ebd6-4288-bc7a-d2d427d 68480

Creecy, R., Wright, R., \& Berg, W. (1979). Minority students in social work doctoral programs: Some considerations for recruitment and retention. Journal of Education for Social Work, $15(3), 58-63$.

Davis, A. (2016). Journaling together: The antiracism project in social work doctoral education. Smith College Studies in Social Work, 86, 355-376.

doi:10.1080/00377317.2016.1222132

Davis, A., \& Livingstone, A. (2016). Sharing the stories of racism in doctoral education: The anti-racism project. Journal of Teaching in Social Work, 36, 197-215. doi:10.1080/08841233.2016.1147521

Ely, R. J., Padavic, I., \& Thomas, D. A. (2012). Racial diversity, racial asymmetries, and team learning environment: Effects on performance. Organization Studies, 33, 341-362. doi:10.1177/0170840611435597

Fong, R. (2014). Framing doctoral education for a science of social work: Positioning students for the scientific career, promoting scholars for the academy, propagating scientists of the profession, and preparing stewards of the discipline. Research on Social Work Practice, 24, 607-615. doi:10.1177/1049731513515055

Garrard, J. (2011). Health sciences literature reviews made easy: The matrix method. Sudbury, MA: Jones \& Bartlett Learning.

Ghose, T., Ali, S., \& Keo-Meier, B. (2017). Diversity in social work doctoral programs: Mapping the road ahead. Research on Social Work Practice, 28(3), 265-271.

Goldman, K. D., \& Schmalz, K. J. (2004). The matrix method of literature reviews. Health Promotion Practice, 5(1), 5- 7. doi:10.1177/1524839903258885

Hanesworth, C. (2017). Neoliberal influences on American higher education and the consequences for social work programmes. Critical and Radical Social Work, 5(1), 41-57. doi:10.1332/204986017X14835298292776 
Haynes, K. S., \& Mickelson, J. S. (2006). Affecting change: Social workers in the political arena. Boston, MA: Allyn \& Bacon.

Holley, K. A., \& Joseph, J. (2013). Increasing diversity in doctoral education: Implications for theory and practice. New Directions for Higher Education, 168.

Hudson, K. D., Shapiro, V. B., Ebiner, I. A., Berenberg, A., \& Bacher, N. (2017). Preparing tomorrow's professoriate: An examination of social justice language in social work $\mathrm{PhD}$ program manuals. Social Work Education, 36, 443- 455.

doi:10.1080/02615479.2017.1297395

Hughes, A., Horner, P., \& Velez Ortiz, D. (2012). Being the diversity hire: Negotiating identity in an academic job search. Journal of Social Work Education, 48, 596-612. doi:10.5175/JSWE.2012.201000101

Klopper, R., Lubbe, S., \& Rugbeer, H. (2007). The matrix method of literature review. Alternation, 14(1), 262-276.

Macías, T. (2015). "Between a rock and a hard place": Negotiating the neoliberal regulation of social work practice and education. Alternative Routes, 26, 251-276.

McBeath, B., Chuang, E., Bunger, A., \& Blakeslee, J. (2014). Under what conditions does caseworker-caregiver racial/ ethnic similarity matter for housing service provision? An application of representative bureaucracy theory. Social Service Review, 88, 134-165. doi:10.1086/675373

National Association of Social Workers. (2015). Social Work speaks. Washington, DC: Author. National Association of Social Workers. (2017). Code of ethics. Retrieved from. https://www.socialworkers.org/About/ Ethics/Code-of-Ethics/Code-of-Ethics-English

National Association of Social Workers. (n.d.). Trump budget would harm well-being of all Americans. Retrieved from http://www.socialworkblog.org/advocacy/2017/04/nasw-trump-budget-would-harm-wellbeing-of-all-americans/

Park, Y., Wahab, S., \& Bhuyan, R. (2017). Feminism in these dangerous times. Affilia, 32, 5-9. doi:10.1177/0886109916686271

Perry, R., \& Limb, G. E. (2004). Ethnic/racial matching of clients and social workers in public child welfare. Children and Youth Services Review, 26, 965-979. doi:10.1016/j.childyouth.2004.05.001

Pinto, R. M., \& Francis, E. A. (2005). Advancing racial and ethnic minority scholars: The social capital benefits of a Minority Fellowship Program. Arete, 29, 45-57.

Reardon, C. (2017). Social Work in a post-election nation: Facing challenges, encouraging hope. Social Work Today, 17 (2), 10.

Reisch, M. (2013). Social work education and the neo-liberal challenge: The US response to increasing global inequality. Social Work Education, 32, 715-733.

doi:10.1080/02615479.2013.809200 
Ross-Sheriff, F., Berry Edwards, J., \& Orme, J. (2017). Relational mentoring of doctoral social work students at historically Black colleges and universities. Journal of Teaching in Social Work, 37, 55-70. doi:10.1080/ 08841233.2016.1270250

Savage, C. (2017, August 1). Justice dept. to take on affirmative action in college admissions. The New York Times. Retrieved from https://www.nytimes.com/2017/08/01/us/politics/trump-affirmative-action-universities.ht $\mathrm{ml}$

Scheyett, A. (2017, March 30). In both the US and UK, social workers can heal society's deep divisions. The Guardian. Retrieved from https://www.theguardian.com/social-care-network/social-life-blog/2017/mar/30/in-both-t he-usand-uk-social-workers-can-heal-societys-deep-divisions

Schiele, J. H., \& Francis, E. A. (1996). The status of former CSWE ethnic minority doctoral fellows in social work academia. Journal of Social Work Education, 32, 31-44. doi:10.1080/10437797.1996.10672282

Schilling, R., Morrish, J. N., \& Liu, G. (2008). Demographic trends in social work over a quarter-century in an increasingly female profession. Social Work, 53, 103-114.

Simon, C. E., Bowles, D. D., King, S. W., \& Roff, L. L. (2004). Mentoring in the careers of African American women in social work education. Affilia, 19, 134-145. doi:10.1177/0886109903262765

Squire, D. (2015). Engaging race and power in higher education organizations through a critical race institutional logics perspective. Journal of Critical Scholarship on Higher Education and Student Affairs, 2(1), 105-121.

Stern, M. J., \& Axinn, J. (2017). Social welfare: A history of the American response to need. New York, NY: Pearson.

Styles O’Neal, G. M., \& Scott, C. A. (1981). Supplying a critical need: Preparing ethnic minority doctoral social work students for leadership roles in mental health. New York, NY: Council on Social Work Education.

Tijerina, M., \& Deepak, A. C. (2014). Mexican American social workers' perceptions of doctoral education and academia. Journal of Social Work Education, 50, 365-378. doi:10.1080/10437797.2014.885277

Trattner, W. I. (2007). From poor law to welfare state: A history of social welfare in America. New York, NY: Simon and Schuster.

Tucker, D. J. (2008). Interdisciplinarity in doctoral social work education: Does it make a difference? Journal of Social Work Education, 44, 115-138. doi:10.5175/JSWE.2008.200700043

Walker, G. E., Golde, C. M., Jones, L., Bueschel, A. C., \& Hutchings, P. (2009). The formation of scholars: Rethinking doctoral education for the twenty-first century. San Francisco, CA: Wiley. 
Williams, J. H. (2017). Political landscape: The times they are a-changing. Social Work Research, 41, 3-5. doi:10.1093/ swr/svx001

Zastrow, C., \& Bremner, J. (2004). Social work education responds to the shortage of persons with both a doctorate and a professional social work degree. Journal of Social Work Education, 40, 351-358. doi:10.1080/ 10437797.2004.10778498 